\title{
Diamond burr superficial keratectomy in the treatment of visually-significant anterior corneal lesions
}

\author{
Ceratectomia superficial com broca de diamante no tratamento de lesões \\ anteriores da córnea
}

\author{
João Baptista Niggro Santiago Malta ${ }^{1}$ \\ Hunson KazSoong'2
}

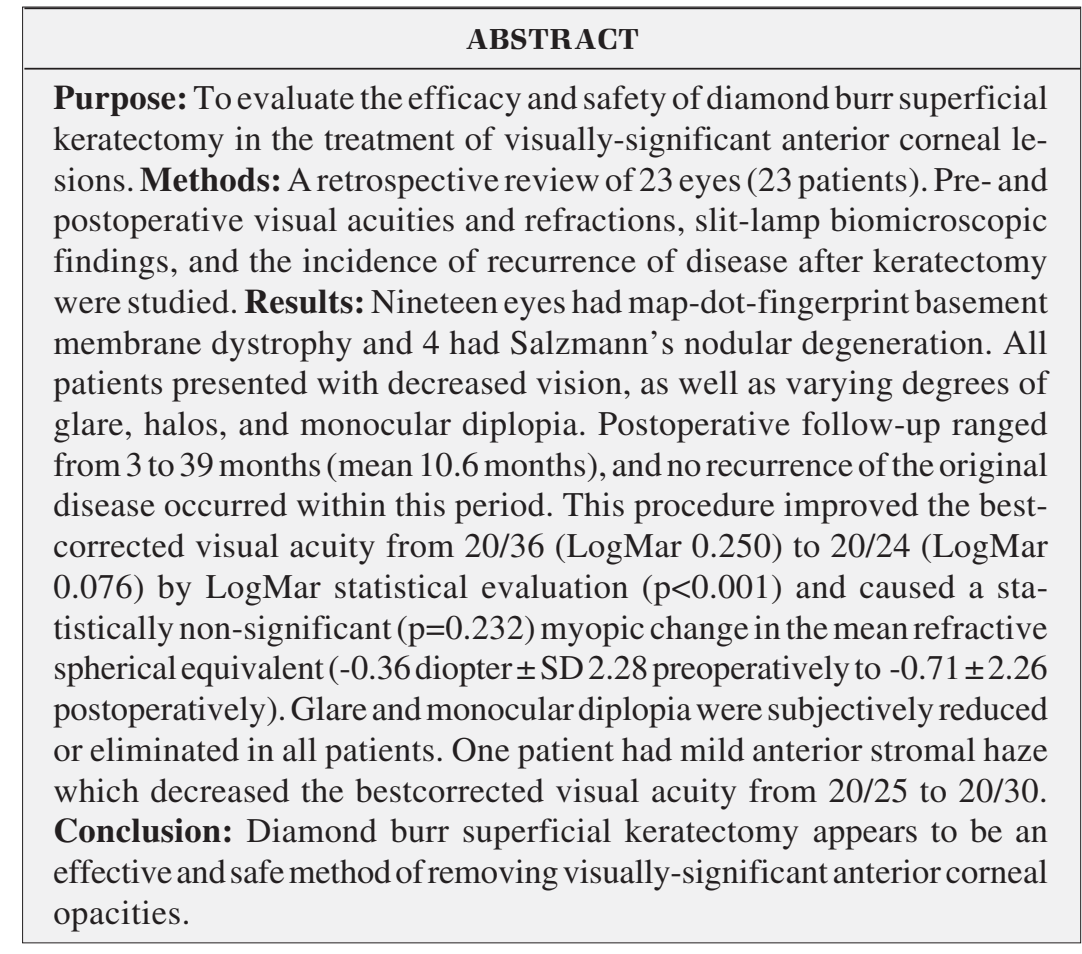

Keywords: Cornea/injuries; Corneal diseases/surgery; Ophthalmologic surgical procedures/ methods; Diamond; Visual acuity; Corneal opacity; Corneal dystrophies, hereditary

Trabalho realizado na Divisão de Córnea, Doenças Externas e Cirurgia Refrativa do W. K. Kellog Eye Center da University of Michigan Medical School - EUA.

Research Fellow - Division of Cornea, External Disease and Refractive Surgery - W. K. Kellogg Eye Center University of Michigan Medical School - USA; Santa Casa de Misericórdia de São Paulo - São Paulo (SP) Brazil.

${ }^{2}$ Professor of Ophthalmology - Division of Cornea, External Disease and Refractive Surgery - W. K. Kellogg Eye Center University of Michigan Medical School USA.

Endereço para correspondência: Hunson Kaz Soong. W. K. Kellogg Eye Center, 1000 Wall Street - Ann Arbor, MI 48105, U.S.A.

E-mail: hksoong@med.umich.edu

Recebido para publicação em 16.07.2007

Última versão recebida em 22.10.2007

Aprovação em 30.10.2007

Nota Editorial: Depois de concluída a análise do artigo sob sigilo editorial e com a anuência do Dr. Vinícius Coral Ghanem sobre a divulgação de seu nome como revisor, agradecemos sua participação neste processo. 


\section{METHODS}

The appropriate institutional review boards for K. W. Kellogg Eye Center approved the Ethics Committee protocol. Informed consent was obtained from each patient before surgical procedure.

The clinical records of all 23 patients who underwent DBSK at the W.K. Kellogg Eye Center (by surgeon HKS) were reviewed. The male-to-female ratio was approximately 1:2 (8 males and 15 females) and the mean patient age was 58 at the time of surgery (range 26-80 years). The mean postoperative follow-up time was 10.6 months (range 3-39) and no eyes had undergone any previous surgery. None of the eyes in the study, including the map-dot-fingerprint (Cogan's or anterior basement membrane) dystrophy cases, had a history of recurrent erosions. In fact, eyes with a history of recurrent corneal erosions were enrolled in a separate retrospective study investigating DBSK for recurrent erosion syndrome ${ }^{(9)}$.

Preoperatively, nineteen eyes had visually-significant map-dot-fingerprint dystrophy and four eyes had Salzmann's nodular degeneration with deep Bowman's layer involvement (precluding simple forceps peeling of the nodules). Blurred vision was the chief complaint in all cases. In addition, all patients complained of varying degrees of glare (e.g. haloes and starbursts) and spurious images (e.g. ghosting and monocular diplopia).

The DBSK surgeries were performed in the minor outpatient procedure room under an operating microscope and under topical anesthesia consisting of proparacaine and/or tetracaine. After sterile preparation and draping, a wire eyelid speculum was inserted. Epithelium was removed from the cornea by gentle scraping with a \#15 Bard-Parker blade and cellulose spears. Whenever possible, abnormal epithelial basement membrane and Salzmann's nodules were peeled off the cornea with jewelers' forceps. The central corneal surface was gently polished with a fine diamond burr (Ugo-Fisch ${ }^{\circledR}$ polishing drill) (Figure 1), using multiple, smooth, circular movements, taking

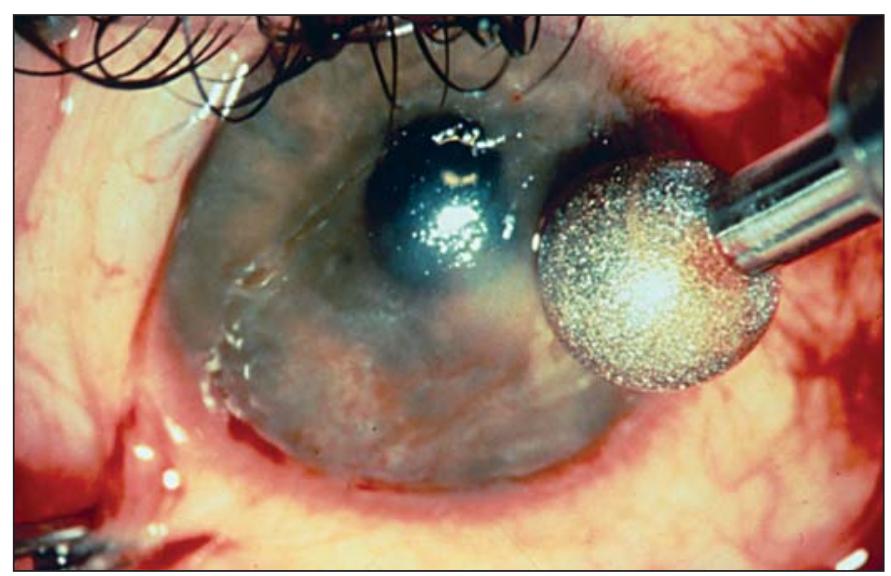

Figure 1 - Fine, diamond-tipped polishing drill tip as seen under the operating microscope special care not to induce irregular topography by either pressing too firmly or tarrying in one focal area too long. In order to assure uncomplicated re-epithelialization, at least a 2-4 $\mathrm{mm}$ rim of corneal epithelium was left intact in the peripheral cornea. The depth of DBSK treatment was kept as minimal as possible in order to reduce the chances of inducing corneal haze or significant refractive errors. A bandage soft-contact lens was applied. A tobramycin-dexamethasone combination (Tobradex ${ }^{\circledR}$ ) eyedrop was given QID and tapered over 1 to 3 weeks. Concurrently, a topical non-steroidal anti-inflammatory agent (diclofenac) was given QID for one week.

The patients were seen at least once during the first postoperative week, and at one and three months thereafter. Some of the patients who were referred from a long distance were eventually returned to their local ophthalmologists for follow-up. Patients who had less than 3 months of postoperative follow-up were excluded from the study. Pre- and postoperative clinical examination included visual acuity measurements, manifest refraction, keratometry, and slit-lamp biomicroscopy.

For statistical evaluation of the pre- and postoperative vision, Snellen acuities were converted to LogMar (log of the minimum angle of resolution) units. Manifest refractions before and after DBSK were converted into spherical equivalents in order to evaluate refractive change after surgery. Although spherical equivalents may obscure some of the details of astigmatism such as axis and irregularity, they do provide a simple, composite gestalt of overall refractive changes without the complexity that is beyond the intended scope of this study. Paired 2-tailed t-test was applied and a P value of less than 0.05 was considered statistically significant.

\section{RESULTS}

By LogMar statistical evaluation, DBSK significantly improved the best-corrected visual acuity from 20/36 (LogMar $0.250 \pm$ SD 0.212) to 20/24 (LogMar 0.076 \pm SD 0.165) $(\mathrm{p}<0.001)$ (Table 1). In addition, all patients subjectively noted resolution of glare, ghosting, and monocular diplopia after DBSK. The mean pre- and postoperative dioptric spherical equivalents by manifest refraction were $-0.36 \pm$ SD 2.28 and $-0.71 \pm$ SD 2.26 , respectively. The resulting $-0.35 \pm \mathrm{SD} 2.26$ diopter change in spherical equivalent from before to after DBSK was statistically non-significant $(\mathrm{p}=0.232)$. No eyes had recurrence of corneal disease within the postoperative follow-up period, although one eye developed mild, diffuse anterior stromal haze after DBSK for map-dot-fingerprint lesions, reducing the best-corrected visual acuity from $20 / 25$ preoperatively to 20/30 postoperatively (patient \#8). The haze appeared to be identical to that sometimes seen after PTK and did not resolve during the one-year follow-up period. Despite these objective findings, the patient subjectively felt that his visual acuity had improved, and that his glare and ghost images were completely resolved. 


\begin{tabular}{|c|c|c|c|c|c|c|c|c|}
\hline Pt.\# & Eye & Preop VA & Postop VA & Diagnosis & Symptoms & F/U mos & Other diagnoses & Postop complications \\
\hline 1 & OS & $20 / 30$ & $20 / 30$ & MDF & & 3 & & \\
\hline 2 & OD & $20 / 20$ & $20 / 15$ & MDF & Yes & 3 & & \\
\hline 3 & OD & $20 / 20$ & $20 / 15$ & MDF & Yes & 3 & & \\
\hline 4 & OD & $20 / 15$ & $20 / 15$ & MDF & Yes & 3 & & \\
\hline 5 & OS & $20 / 25$ & $20 / 20$ & MDF & & 37 & & \\
\hline 5 & OD & $20 / 20$ & $20 / 20$ & MDF & Yes & 24 & & \\
\hline 6 & OD & $20 / 40-2$ & $20 / 20-3$ & MDF & & 4 & & \\
\hline 7 & OS & $20 / 30$ & $20 / 25$ & MDF & & 35 & ARMD; Glaucoma & \\
\hline 8 & OS & $20 / 25$ & $20 / 30$ & MDF & & 12 & & Mild diffuse haze \\
\hline 9 & OS & $20 / 60$ & $20 / 40$ & MDF & & 39 & Cataract; Dry eyes & \\
\hline 10 & OS & $20 / 30$ & $20 / 20$ & MDF & & 4 & & \\
\hline 11 & OD & $20 / 50-2$ & $20 / 20$ & Salzmann & & 6 & Cataract; Dry eyes & \\
\hline 12 & OS & $20 / 60-2$ & $20 / 50$ & MDF & & 3 & Cataract & \\
\hline 12 & OD & $20 / 70$ & $20 / 50+2$ & MDF & & 4 & Cataract & \\
\hline 13 & OD & $20 / 100$ & $20 / 25$ & MDF & & 3 & Cataract & \\
\hline 14 & OD & $20 / 50-2$ & $20 / 25$ & Salzmann & & 5 & Dry eyes & \\
\hline 15 & OD & $20 / 60$ & $20 / 40$ & Salzmann & & 3 & Cataract; PPMD & \\
\hline 16 & OD & $20 / 40$ & $20 / 20$ & MDF & & 11 & & \\
\hline 17 & OS & $20 / 20-2$ & $20 / 15$ & MDF & Yes & 28 & Cataract & \\
\hline 18 & OS & $20 / 40$ & $20 / 40$ & MDF & Yes & 3 & Cataract; Fuchs & \\
\hline 19 & OS & $20 / 40$ & $20 / 15$ & MDF & Yes & 3 & Old corneal scar & \\
\hline 20 & OD & $20 / 30$ & $20 / 20$ & MDF & & 3 & Dry eyes & \\
\hline 21 & OS & $20 / 25$ & $20 / 20+2$ & MDF & Yes & 4 & & \\
\hline 22 & OS & $20 / 20$ & $20 / 20$ & MDF & & 17 & Dry eyes & \\
\hline 23 & OS & $20 / 40$ & $20 / 40$ & Salzmann & Yes & 11 & ARMD; Fuchs & \\
\hline
\end{tabular}

\section{DISCUSSION}

The anterior corneal surface is an important refractive interface, in which corneal opacities and irregularities could cause substantial visual disturbances, oftentimes incommensurate to the disarmingly mild appearance of the lesions. It may be an overlooked etiology of painless, waxing and waning visual disturbances ${ }^{(12)}$. Retroillumination, computerized topographical studies, and retinoscopy may be utilized to delineate the milder opacities and to elucidate the induced optical distortions.

Our study suggests that DBSK is a safe and effective surgical treatment for the removal of visually-significant anterior corneal lesions, and its results appear similar to that of excimer laser PTK ${ }^{(3-4,8)}$. In addition, DBSK has the benefit of simplicity, low cost, easy availability, and minimal refractive effects. To some degree, the paucity of large refractive shifts and postoperative corneal haze in our study may be due to the relative superficiality of corneal pathology in our patients. None of our cases required excision much beyond deep Bowman's layer.

Both PTK and DBSK can result in either hyperopic or myopic shifts ${ }^{(3)}$. A hyperopic shift is expected to be more common when central corneal tissue is removed because this flattens the corneal curvature. Since peripheral corneal opa- cities rarely cause visual loss, myopic shifts are relatively uncommon in this kind of surgery. Our post-DBSK refractive shift was statistically non-significant and even showed a slight trend towards myopia. This is most likely because all of our patients had very superficial corneal pathology not requiring deep central stromal keratectomy. On the other hand, deeper DBSK treatments may be expected to produce more hyperopia and perhaps more astigmatism as well.

The postoperative anterior corneal haze in patient 8 appears very similar to that seen after excimer laser treatment of the corneal surface, such as PTK and photorefractive keratectomy $(\mathrm{PRK})^{(4,8)}$. It would follow that anterior corneal haze seems to be generically associated with the superficial keratectomy surgery itself, irrespective of the means of achieving anterior corneal removal. Violation of Bowman's layer may be the common denominator in the occasional development of haze $^{(4,8)}$. None of the eyes in our study had stromal pathology necessitating keratectomy deeper than Bowman's layer; therefore, the question still remains as to whether more cases of corneal haze would have been encountered if more of the eyes in our study required deeper keratectomy.

The stability of our postoperative results with respect to refraction, best-corrected visual acuity, and recurrence of disease appears promising, but the follow-up period averaging 10.6 months is relatively short. A longer postoperative fol- 
low-up time is necessary for a more reliable assessment of clinical stability.

For patients with deeper stromal opacities, we have been preferring excimer laser PTK over DBSK because we believe the former produces a more even and better-controlled removal of stroma than manual techniques such as DBSK would allow. However, for very superficial corneal pathology, DBSK appears to be an excellent alternative to PTK. Occasionally, in very superficial lesions, membranectomy by simple peeling may be sufficient ${ }^{(13)}$. In all our patients, however, attempts at simple peeling of the lesions were unsuccessful and DBSK was necessitated.

\section{RESUMO}

Objetivo: Avaliar a eficácia e segurança da ceratectomia superficial com broca de diamante no tratamento das lesões anteriores da córnea. Métodos: Foi realizado estudo retrospectivo de 23 olhos de 23 pacientes. Foram avaliados acuidade visual e refração pré e pós-operatório, biomicroscopia e incidência de recorrência da doença após ceratectomia. Resultados: Dos 23 olhos avaliados, 19 olhos apresentavam distrofia da membrana basal (map-dot-fingerprint) e 4 degeneração nodular de Salzmann. Todos os pacientes apresentavam diminuição da acuidade visual, assim como graus variados de ofuscamento, halos e diplopia monocular. O seguimento pósoperatório variou entre 3 e 39 meses (média de 10,6 meses) e não houve recorrência da doença original nesse período. $\mathrm{O}$ procedimento melhorou a acuidade visual com melhor correção de 20/36 (LogMar 0,250) para 20/24 (LogMar 0,076) com $\mathrm{p}<0,001$. Em relação as mudanças refracionais não houve significância $(\mathrm{p}=0,232)$ sendo o equivalente esférico pré-operatório de $-0,36 \pm 2,28 \mathrm{DE}$ e pós-operatório de -0,71 $\pm 2,26 \mathrm{DE}$. As queixas de ofuscamento e diplopia monocular diminuíram ou foram eliminadas em todos os pacientes. Apenas 1 paciente apresentou nubécula no estroma anterior com diminuição da acuidade visual com melhor correção de 20/25 para 20/30.
Conclusão: Ceratectomia superficial com broca de diamante parece ser método efetivo e seguro para remover opacidades anteriores de córnea.

Descritores: Córnea/lesões; Procedimentos cirúrgicos oftalmológicos/métodos; Diamante; Acuidade visual; Opacidade da córnea; Distrofias hereditárias da córnea

\section{REFERENCES}

1. Soong HK, Katz DG, Farjo AA, Sugar A, Meyer RF. Central lamellar keratoplasty for optical indications. Cornea. 1999;18(3):249-56.

2. McDonnell PJ, Seiler T. Phototherapeutic keratectomy with excimer laser for Reis-Bückler's corneal dystrophy. Refract Corneal Surg. 1992;8(4):306-10.

3. Maloney RK, Thompson V, Ghiselli G, Durrie D, Waring GO $3^{\text {rd }}$, O'Connell M. A prospective multicenter trial of excimer laser phototherapeutic keratectomy for corneal vision loss. The Summit Phototherapeutic Keratectomy Study Group. Am J Ophthalmol. 1996;122(2):149-60.

4. Campos M, Nielsen S, Szerenyi K, Garbus JJ, McDonnell PJ. Clinical follow-up of phototherapeutic keratectomy for treatment of corneal opacities. Am J Ophthalmol. 1993;115(4):433-40.

5. O'Brart DP, Gartry DS, Lohmann CP, Patmore AL, Kerr Muir MG, Marshall J. Treatment of band keratopathy by excimer laser phototherapeutic keratectomy: surgical techniques and long term follow up. Br J Ophthalmol. 1993; 77(11):702-8

6. Rogers C, Cohen P, Lawless M. Phototherapeutic keratectomy for Reis Bucklers' corneal dystrophy. Aust N Z J Ophthalmol. 1993;21(4):247-50.

7. Förster W, Grewe S, Busse H. [Clinical use of the excimer laser in treatment of surface corneal opacities - therapeutic strategy and case reports]. Klin Monatsbl Augenheilkd. 1993;202(2):126-9. German.

8. Poirier L, Coulon P, Williamson W, Mortemousque B, Verin P. [Results of therapeutic photo-keratectomy using the Excimer laser. A propos of 12 cases]. J Fr Ophtalmol. 1994;17(4):262-70. French.

9. Soong HK, Farjo Q, Meyer RF, Sugar A. Diamond burr superficial keratectomy for recurrent corneal erosions. Br J Ophthalmol. 2002;86(3):296-8.

10. Sridhar MS, Rapuano CJ, Cosar CB, Cohen EJ, Laibson PR. Phototherapeutic keratectomy versus diamond burr polishing of Bowman's membrane in the treatment of recurrent corneal erosions associated with anterior basement membrane dystrophy. Ophthalmology. 2002;109(4):674-9. Comment in: Ophthalmology. 2003;110(9):1855; author reply 1855.

11. Bokosky JE, Meyer RF, Sugar A. Surgical treatment of calcific band keratopathy. Ophthalmic Surg. 1985;16(10):645-7.

12. Reed JW, Jacoby BG, Weaver RG. Corneal epithelial basement membrane dystrophy: an overlooked cause of painless visual disturbances. Ann Ophthalmol. 1992;24(12):471-4.

13. Wood TO, Griffith ME. Surgery for corneal epithelial basement membrane dystrophy. Ophthalmic Surg. 1988;19(1):20-4. 